\title{
Resolusi Konflik Kepemilikan Aset Publik Antara Kabupaten Tasikmalaya dan Kota Tasikmalaya Tahun 2019
}

\section{Conflict Resolution of Public Asset Ownership Between Tasikmalaya District and City in 2019}

\author{
Diah Wahyuningsih", Dian Eka Rahmawati², David Efendi ${ }^{3}$ \\ 1,2,3Magister Ilmu Pemerintahan, Universitas Muhammadiyah Yogyakarta. \\ E-mail: 1diahwahyuningsih918@gmail.com,2dianekarahmawati93@gmail.com,3defendi83@gmail.com
}

\section{ARTICLE INFO}

Keywords: conflict resolution, territorial expansion, public assets.

Kata Kunci: resolusi konflik, pemekaran wilayah, aset publik.

How to cite:

Wahyuningsih, D., Rahmawati, D. E., \& Efendi, D. (2020).

Resolusi Konflik

Kepemilikan Aset Publik

Antara Kabupaten

Tasikmalaya dan Kota

Tasikmalaya Tahun 2019. JAKPP (Jurnal

Analisis Kebijakan dan

Pelayanan Publik), 6(1), $15-34$.

\begin{abstract}
This study discusses the conflict resolution of regional asset ownership between Tasikmalaya Regency and Tasikmalaya City. The purpose of this paper is to describe how the conflict resolution process carried out by the two regional governments after a meeting between the Governor of West Java, the Regent of Tasikmalaya, and the Mayor of Tasikmalaya in 2013, and the State Prosecutor's Office in 2019. In writing this article the author uses the method research studies literature. The results of this paper explain what factors are causing the conflict over assets and the methods used to resolve the conflict.
\end{abstract}

\begin{abstract}
Abstrak
Studi ini membahas resolusi konflik kepemilikan asset daerah antara Kabupaten Tasikmalaya dengan Kota Tasikmalaya. Tujuan penulisan ini adalah untuk mendeskripsikan bagaimana proses resolusi konflik yang dilakukan oleh kedua pemerintah daerah tersebut setelah adanya pertemuan antara pihak Gubernur Jawa Barat, Bupati Tasikmalaya, dan Walikota Tasikmalaya pada tahun 2013, dan Kejaksaan Negeri pada tahun 2019. Dalam menulis artikel ini penulis menggunakan metode penelitian studi literatur. Hasil dari penulisan ini menjelaskan faktor-faktor apa saja yang menjadi penyebab terjadinya konflik sengketa perbutan aset dan metodemetode yang digunakan dalam menyelesaikan konflik tersebut.
\end{abstract}

\section{Pendahuluan}

Perjalanan penyelenggaran otonomi daerah, pemerintah telah mengeluarkan setidaknya tiga peraturan perundang-undangan tentang Pemerintahan Daerah. Mulai dari Undang-Undang Nomor 22 Tahun 1999, Undang-Undang Nomor 32 Tahun 2004 dan Undang-Undang Nomor 23 Tahun 2014 Tentang Pemerintahan Daerah. Dalam proses pembentukan daerah otonom semuanya berdasarkan amanat yang ada dalam Pasal 18 ayat (5) UUD 1945 tentang otonomi seluas-luasnya. Sehingga hal ini mengakibatkan proses pembentukan daerah otonom dalam pelaksanaannya dirasa sangat "mencemaskan" akan terjadinya disintegrasi. 
Menurut Djoko Harmantyo dalam (Fauzan, 2014) salah satu permasalahan yang tidak bisa dilepaskan begitu saja di dalam proses sengketa kewenangan antar daerah, pada daerah pemekeran adalah permasalahan menarik garis batas wilayah. Tujuan desentralisasi dan otonomi daerah membutuhkan banyak pertimbangan dari berbagai aspek. Konflik keruangan merupakan salah satu satu aspek tersebut. Fakta lain yang tidak dapat disanggah adalah konflik/sengketa yang terjadi antara daerah hasil pemekaran dengan daerah induk.

Tasikmalaya merupakan sebuah Kabupaten di Jawa Barat yang melakukan pemekaran daerah menjadi Kabupaten dan Kota setelah pemekaran. Sengketa aset daerah ini memerlukan waktu hingga 18 tahun dari Tahun 2001-2019. Perebutan aset tersebut sangat panjang waktunya daripada daerah-daerah lain di Jawa Barat yang melakukan pemekaran seperti seperti Kota Depok (1999), Kota Cimahi (2001), Kota Bekasi (2001), Kota Banjar (2002), Kabupaten Bandung Barat(2007), Kabupaten Pangandaran (2012), dan Kabupaten Depok (2012) (Sofa, 2016).

Sumber-sumber pendapatan yang cukup akan berdampak baik terhadap penyelenggaraan urusan pemerintahan daerah. Aset-aset yang dimiliki oleh daerah merupakan salah satu sumber sumber pendapatan daerah. Sehingga pengaruh aset dalam pendapatan yang di peroleh daerah sangat penting. Namun realitas yang terjadi pasca-pemekaran suatu daerah, salah satu pemicu permasalahan antar daerah yaitu perebutan aset daerah itu sendiri (Rizky, 2014). Sehingga bisa disimpulkan, bahwasanya konflik dapat timbul ketika objek yang bernilai dianggap mempunyai hak untuk dimiliki oleh masing-masing pihak yang bersengketa

Sengketa aset yang diperebutkan oleh kedua Pemerintah Daerah ini dilatarbelakangi karena banyaknya aset Pemerintah Kabupaten Tasikmalaya yang ada di wilayah Pemerintah Kota Tasikmalaya. Pada waktu itu, Pemerintah Kabupaten Tasikmalaya menolak menyerahkan 85 asetnya pada Pemerintah Kota Tasikmalaya, hingga Kementerian Dalam Negeri meminta pemerintah Jawa Barat turut menengahi persoalan aset itu sejak tahun 2008 hingga tahun 2013 (Sofa, 2016).

Sengketa aset yang diperebutkan oleh Kabupaten/Kota Tasikmalaya dikarenakan Pemerintah Kabupaten Tasimalaya menolak menyerahkan asetnya pada Pemerintah Kota Tasikmalaya, hingga Kementerian Dalam Negeri meminta pemerintah Jawa Barat turut menengahi persoalan aset itu sejak tahun 2008 hingga tahun 2013. Sehingga pemerintah Kabupaten Tasikmalaya mau tidak mau harus membangunan pemerintahan yang baru. Pada tahun 2013 pemerintah provinsi berinisiatif untuk membuat resolusi konflik untuk dapat menyelesaikan permasalahan aset ini dengan win-win solution.

Resolusi konflik adalah cara menyelesaikan masalah antara kedua belah pihak yang bermasalah baik melalui proses negosiasi dan kompromi. Sehingga mendapatkan titik terang dalam menyelesaikan masalah. Selain itu resolusi konflik menawarkan cara-cara penyelesaian masalah yang dianggap demokratis. Pada tahun 2019, upaya mediasi yang pertama dilakukan tanggal 16 september, dalam hal ini Kejaksaan Negeri sebagai pihak mediator. Permasalahan yang menjadi ketertarikan penulis untuk menganalisis permasalahan di atas yaitu bagaimana resolusi konflik 
yang dilakukan oleh Kejaksaan Negeri untuk menyelesaikan konflik perebutan aset antar kedua belah Pemerintah Daerah tersebut.

\section{Kajian Literatur}

\section{Konflik}

Menurut Antonius (dalam Sona, 2016) konflik merupakan permasalahan yang dilakukan oleh individu atau kelompok yang berdampak menganggu orang lain. Menurut Ramlan Subakti (dalam Rizky, 2014) dalam ilmu politik istilah konflik sering dihubungkan dengan kekerasan. Benturan dalam makna konflik, sering dijelaskan seperti disparitas keinginan, kompetisi serta perselisihan antara individu dengan individu, kelompok dengan pemerintah. Secara umum konflik politik sering dijelaskan sebagai persaingan, disparitas pendapat, dan perselisihan diantara beberapa individu, grup ataupun organisasi dalam upaya atau meraih sumber dari hasil ketetapan yang sebelumnya sudah diatur dan diterapkan pemerintah. Menurut Sona (2016) ada berbagai macam jenis konflik, diantaranya sebagai berikut:

1. Dilihat dari segi pihak yang terlibat dalam konflik

a. Konflik individu dengan individu. Konflik seperti ini terjadi antara satu orang dengan orang yang lainnya. Contohnya karyawan dengan bos, pegawai dengan atasannya, manager dengan branch manager.

b. Konflik individu dengan kelompok. Jenis konflik seperti ini seringkali terjadi antara atasan dengan bawahannya, kepala sekolah dengan para guru dan lain sebagainya.

c. Konflik kelompok dengan kelompok, banyak contoh kasus dari konflik ini misalnya geng motor dengan geng anak SMA, antar suporter sepak bola, fans club artis A dan B, dan lain sebagainya.

2. Dilihat dari segi dampak yang diakibatkan

a. Fungsional. Konflik fungsional adalah jenis konflik yang memberikan dampak positif untuk kedua belah pihak yang bermasalah karena dapat bersifat menguntungkan dan bermanfaat.

b. Infungsional. Konflik ini adalah kebalikan dari jenis konflik fungsional karena bersifat merugikan baik untuk individu maupun kelompok yang bermasalah.

\section{a. Faktor Penyebab Konflik}

Beberapa faktor-faktor penyebab konflik menurut Sona (2016), sebagai berikut:

1. Tringgers (Pemicu), kejadian yang dapat menyebabkan konflik terjadi, tetapi tidak dibutuhkan serta tidak cukup untuk menjelaskan konflik.

2. Privotal Factor or Root Causes adalah faktor utama atau akar permasalahan yang harus diselesaikan segera.

3. Mobilizing factors, faktor yang dapat dimobilisasi oleh kelompok bertujuan melakukan suatu tindakan. 
4. Aggravating factors, faktor yang dapat memperburuk permasalahan. Faktor ini menjadi faktor pendorong dalam mobilizing factors dan privotal factors.

\section{Resolusi Konflik}

Menurut Levine (dalam Meriwijaya, 2017) menjelaskan bahwa Resolusi pada webster dictionary dapat dijelaskan sebagai berikut (1) suatu langkah dalam membahas masalah, (2) proses memecahkan, menghapus, dan menghilangkan masalah secara bersama-sama. Menurut Fisher et, al (2017), resolusi konflik adalah cara menyelesaikan permasalahan sebab akibat serta menciptakan dan memperbaiki kesalahpahaman yang terjadi antara pihak-pihak yang bermasalah. Sedangkan Mindes (dalam Sona, 2016) berpendapat resolusi konflik adalah aspek utama dalam pembangunan moral dan sosial yang membutuhkan cara dan keterampilan tersendiri untuk menyelesaikan permasalahan antara kedua belah pihak yang bermasalah, caracara menyelesaikan masalah tersebut seperti bernegosiasi, kompromi dan menerapkan sikap adil.

Meskipun konflik merupakan bagian dari kehidupan, akan tetapi jika konflik tersebut merugikan diri sendiri maupun pihak lain maka harus diselesaikan. Berikut ini adalah beberapa jenis metode penyelesaian konflik menurut Sona (2016), yaitu:

1. Penanganan konflik (conflict settlement), upaya mengakhiri tingkah laku kekerasan dengan mencapai kesepakatan perdamaian.

2. Manajemen konflik (conflict management), bertujuan untuk membatasi dan menghindari kekerasan yang mungkin terjadi di waktu yang akan datang dengan cara mendukung perubahan tingkah laku yang positif pada pihakpihak yang terlibat.

3. Resolusi konflik (conflict resolution), yaitu membahas berbagai penyebab konflik dan mencoba untuk membangun hubungan baru dan abadi di antara kelompok-kelompok yang saling bertikai.

4. Transformasi konflik (conflict transformation), membahas sumber politik dan sosial yang lebih luas dari suatu konflik dan mencoba untuk mentransformasikan energi negatif peperangan menjadi perubahan sosial dan politik yang bersifat positif.

Dari penjelasan para ahli diatas dapat diambil kesimpulan bahwa resolusi konflik adalah cara menyelesaikan masalah antara kedua belah pihak yang bermasalah baik melalui proses negosiasi dan kompromi, sehingga mendapatkan titik terang dalam menyelesaikan masalah. Selain itu resolusi konflik menawarkan caracara penyelesaian masalah yang dianggap demokratis seperti memberikan kesempatan kepada kedua belah pihak yang berseteru untuk memilih cara yang tepat dalam menyelesaikan masalah ataupun melibatkan pihak ketiga sebagai pihak penengah yang bersifat netral dan adil. 


\section{a. Model Resolusi Konflik}

\section{Model Resolusi Konflik Non Violet/Tanpa Kekerasan}

Menurut M.A Rahim (dalam Meriwijaya, 2017) model resolusi konflik non violet atau tanpa kekerasan adalah pemilihan cara menyelesaikan konflik oleh pihak-pihak yang bermasalah dengan tidak menggunakan kekerasan, baik kekerasan verbal maupun non verbal, dan kekerasan fisik. Model resolusi konflik seperti ini sangat berguna apabila kedua belah pihak yang berkonflik membutuhkan satu sama lain dan mempunyai tujuan yang sama. Sehingga salah satu pihak dapat membuat atau memaksakan pihak lawan untuk tetap diam dan tidak melakukan sesuatu yang tidak berguna bagi pihak lawan.

\section{Model Resolusi Konflik dengan Modus Kompromi/Negosiasi}

Menurut Soekanto, et.al (dalam Meriwijaya, 2017) model ini merupakan cara menyelesaikan konflik dengan mengambil jalan tengah berdasarkan kesepakatan kedua belah pihak yang berkonflik dan mempunyai hubungan kerjasama yang sedang. Modus kompromi/ negosiasi ini dilakukan dengan strategi take and give, sehingga terdapat cara pemecahan masalah yang memuaskan kedua belah pihak.

\section{Model Resolusi Konflik dengan Modus Integrasi/ Kolaborasi}

Menurut Thomas dan Kolman (dalam Meriwijaya, 2017) model resolusi konfik dengan modus integrasi/kolaborasi adalah menyelesaikan konflik dengan cara berdiskusi, menganlisis konflik, dan mempertimbangkan kembali alasan-alasan kedua belah pihak yang berkonflik sampai didapatkan keputusan yang bersifat memaksa kedua belah pihak untuk menerimanya. Tujuan dari model resolusi konflik ini adalah mendapatkan penyelesaian masalah, sehingga mampu memenuhi keinginan individu atau kelompok yang berkonflik.

\section{Model Resolusi Konflik dengan Modus Mediasi}

Menurut Soerjono Soekanto (dalam Meriwijaya, 2017), model resolusi konflik dengan modus medisi adalah proses menyelesaikan masalah dengan cara melibatkan pihak ketiga sebagai mediator atau fasilitator. Pemilihan modus ini dipilih atau diterapkan karena kedua belah pihak tidak dapat menyelesaikan masalahnya sendiri sehingga membutuhkan pihak ketiga sebagai mediator yang dapat menjadi penengah untuk kedua belah pihak. Mediasi ini dilakukan di tempat dan waktu yang sama serta menghadirkan kedua belah pihak yang terkait, sehingga dalam mediasi ini membutuhkan waktu dan take and give. Mediator disini sifatnya hanya sebagai penasehat saja sehingga tidak punya kewenangan untuk memberikan keputusan dalam menyelesaikan permasalahan tersebut namun biasanya pendapat yang diberikan oleh mediator adalah jalan tengah yang adil untuk kedua belah pihak. Mediator dipilih karena bersifat netral tidak berpihak ke salah satu pihak yang berkonflik.

\section{Model Resolusi Konflik Arbitrasi}

Menurut Kenneth W.Thomas dan Kilmann (dalam Meriwijaya, 2017) model resolusi konflik Arbitrasi adalah penyelesaian konflik yang terdapat keterlibatan 
pihak ketiga yang bersifat netral dan mempunyai kewenangan dapat memberikan keputusan terbaik yang bersifat mengikat untuk kedua belah pihak.

\section{Model Resolusi Konflik Adjukasi}

Menurut Kenneth W.Thomas dan Kilmann (dalam Meriwijaya, 2017) model resolusi konflik Adjukasi adalah penyelesaian konflik dengan perkara di pengadilan. Model resolusi konflik adjukasi dipilih apabila kedua belah pihak tidak menemukan kesepakatan dalam proses kompromi maupun arbitrasi, sehingga perlu diselesaikan di pengadilan.

Menurut Derr (dalam Meriwijaya, 2017) dari beberapa model konflik yang sudah dijelaskan diatas model kolaborasi adalah model resolusi konflik yang paling banyak dipilih dan disukai. Model ini dapat memperbaiki kesalahpahaman antara pihakpihak yang berkonflik. Beberapa alasan kedua belah pihak yang berkonflik memilih model resolusi konflik ini adalah sebagai berikut:

- Mendapatkan solusi dan tujuan yang tepat dan dapat dikompromikan untuk kedua belah pihak

- Menjadi tujuan untuk dapat memperlajari lebih jauh lawan konflik

- Kedua belah pihak yang berkonflik ini tidak mempunyai kekuasaan untuk memaksakan kehendaknya.

\section{Pengertian Aset}

Menurut Mahmudi (dalam Rizky, 2014), aset daerah merupakan kekayaan daerah yang dimiliki serta dikuasai pemerintah daerah tersebut, yang dibeli atau diperoleh atas beban APBD maupun berasal dari hasil lainnya yang sah. Aset daerah bisa dikelompokan secara umum menjadi dua bentuk, yaitu aset keuangan dan aset non keuangan. Kas dan setara kas merupakan bagian dari aset keuangan. Sedangkan aset tetap, aset lainnya dan persediaan merupakan aset non keuangan, kemudian aset daerah dilihat dari penggunaanya dikategorikan menjadi tiga, yaitu: pertama, aset daerah yang dipakai untuk operasional pemerintah daerah.

Berdasarkan dari penggunaanya, aset daerah dikategorikan menjadi tiga, yaitu pertama, aset daerah yang dipakai buat operasional pemerintah daerah. Kedua, aset daerah yang dipakai masyarakat dalam kegiatan pelayanan publik publik. Ketiga, aset daerah yang tidak dipakai untuk pemerintah ataupun publik. Pada dasarnya aset jenis ketiga merupakan aset yang dalam pemanfaatanya belum optimal. Demi kelancaran kegiatan pemerintah pada dasarnya aset daerah menjadi hak bagi daerah pemekaran.

\section{Metode Penelitian}

Studi literatur atau studi pustaka adalah penelitian yang dilakukan berdasarkan data yang didapat dari karya tertulis, termasuk hasil penelitian yang baik yang sudah ataupun belum dipublikasikan (Embun, 2012). Riset pustaka bukan 
hanya sekedar langkah pertama dalam menyiapkan kerangka penelitian, selain itu dalam mendapatkan data menggunakan sumber-sumber perpustakaan (Zed, 2012). Penelitian dengan studi literatur adalah penelitian yang persiapannya sama dengan penelitian lainnya akan tetapi sumber dan metode pengumpulan data dengan mengambil data di pustaka, membaca, mencatat, dan mengolah bahan penelitian. Dalam menulis artikel ini penulis menelaah beberapa jurnal terkait dengan resolusi konflik perebutan aset daerah pasca pemekaran wilayah. Langkah pertama yang dilakukan penulis adalah dengan melakukan analisis studi literatur pada jurnal-jurnal yang membahas tentang resolusi konflik perebut aset daerah. Hasil dari berbagai literatur ini akan digunakan penulis untuk membahas dan mengidentifikasi resolusi konflik kepemilikan asset publik antara kabupaten tasikmalaya dan kota tasikmalaya.

\section{Hasil dan Pembahasan}

\section{Resolusi Konflik Kepemilikan Asset Publik Antara Kabupaten Tasikmalaya dan Kota Tasikmalaya}

Fenomena yang berkembang pesat sejak awal reformasi yang mengiringi penyelenggaraan pemerintah daerah di Indonesia salah satunya adalah pemekaran daerah. Pemekaran daerah dalam pelaksanaanya diharapkan dapat membawa kesejahteraan bagi masyarakat, bisa meningkatkan pelayanan, serta bisa menjadikan daerah semakin mandiri dan demokratis. Pada saat ini fakta pemekaran yang muncul adalah sekitar $80 \%$ daerah pemekaran belum bisa menunjukan peningkatan pembangunan hal ini disebabkan karena adanya faktor konflik keuangan (Prayitno, 2014).

Meskipun penataan penyelenggaran pemerintahan sudah sesuai dengan pedoman yang ada namun apabila dilihat secara global belum terdapat satupun daerah otonomi baru yang bisa di kelompokan kedalam kelompok mampu. Kurangnya kemampuan DOB dalam memformulasikan dengan benar kewenangan maupun urusan yang akan diselenggarakan agar pas dengan kondisi, kebutuhan masyarakat serta karakterisitik daerah menjadi penyebab belum adanya DOB yang bisa meningkatkan pembangunan di daerahnya (Fauzan, 2014).

Ada beberapa karya ilmiah sebelumnya yang membahas mengenai pemekaran daerah, dua diantaranya memakai Tasikmalaya sebagai objek studinya. Pertama ada dari Ahmad Rizky Sadali berjudul Dampak Pemekaran dan Konflik Pemerintah Daerah (Studi Kasus Pemekaran Kabupaten Tasikmalaya dan Sengketa aset pascapemekaran periode 2001-2013). Secara garis besar, penelitian ini berupaya untuk memaparkan dampak pemekaran wilayah yang banyak terjadi di Indonesia pasca diterbitkannya UndangUndang Nomor 22 Tahun 1999 dengan menganalisis dampak pemekaran di wilayah Kabupaten Tasikmalaya.

Dengan menggunakan perspektif dari Vedi Hadiz, hasil dari penelitian ini menunjukan bahwa kepentingan-kepentingan elit lah yang menimbulkan permasalahan di daerah pasca pemekaran karena tidak ada ketidakseriusan untuk mensejahterakan rakyat. Dari kasus yang terjadi di Kabupaten Tasikmalaya menurut 
penelitian ini akibat adanya pemekaran malah membuat semakin terpuruk sejak ibukotanya menjadi daerah otonom baru dan juga sengketa aset yang muncul antara Pemerintah Kabupaten dan Pemerintah Kota Tasikmalaya.

Kedua dari Muhammad Rizky berjudul Konflik Aset di Daerah Pemekaran Studi Konflik Serah Terima Aset Pasar Tradisional di Tangerang Selatan. Penelitian ini memaparkan terkait konflik aset di daerah pemekaran dengan permasalahan serah terima aset di Kota Tangerang Selatan khususnya aset pasar tradisional yang sekarang masih terkendala. Penelitian ini bertujuan untuk mengetahui penyebab, dampak, dan proses penyelesaian. Beberapa hal yang menjadi faktor penghambat dalam serah terima aset diantaranya faktor struktural, faktor kepentingan, faktor hubungan masyarakat, dan faktor data. Proses penyelesaian yang ditempuh adalah dengan mempertemukan kedua belah pihak untuk menyelesaikan permasalahan serah terima aset.

Ketiga dari Muhammad Fauzan dan Kadar Pamuji berjudul Model Kerjasama Antar Daerah dalam Penyelesaian Sengketa Kewenangan Pada Daerah Kabupaten/Kota Hasil Pemekaran. Penelitian ini memaparkan pertama, selain memberikan keuntungan dalam proses percepatan, peningkatan pelayanan masyarakat dan pembangunan kebijakan pemekaran daerah juga dapat menimbulkan konflik yang berhubungan dengan kewenangan pengelolaan atas aset daerah yang mana hal ini dapat mengakibatkan harmonisasi hubungan antara daerah induk dengan daerah hasil pemekaran menjadi berpengaruh.

Kedua, didalam menyelesaikan sengketa kewenangan antara daerah induk dengan daerah hasil pemekaran menggunakan model kerjasama melalui dua pendekatan, yaitu pendekatan legal formal dan pendekatan kearifal lokal, memakai terminologi "kepentingan seluruh masyarakat dan saling menghormati" tanpa memandang batas wilayah administratif daerah hasil pemekaran dengan daerah induk merupakan metode memberikan "sentuhan" argumentasi yang "menyentuh" nilai emosional masyarakat. Artinya tanpa memandang apakah itu secara administrasi daerah hasil pemekaran atau daerah induk, kepentingan masyarakat harus diutamakan. Tasikmalaya merupakan sebuah Kabupaten di Jawa Barat yang melakukan pemekaran daerah menjadi Kabupaten dan Kota setelah pemekaran. Sengketa aset daerah yang memerlukan waktu hingga 12 tahun dari Tahun 2001-2013. Perebutan aset ini sangat panjang waktunya daripada daerah-daerah lain di Jawa Barat.

\section{a. Faktor Penyebab Konflik \\ 1. Tringgers}

Sejak diterbitkannya Undang-Undang nomor 10 tahun 2001 tentang Pembentukan Kota Tasikmalaya pada tanggal 17 Oktober 2001, setelah melalui proses pemekaran daerah dari Kabupaten Tasikmalaya maka Kota Tasikmalaya resmi menjadi daerah otonom baru. Dalam penyelenggaraan pemerintahan daerah terjadi berbagai dinamika. Sampai sekarang sejak Kota Tasikmalaya memisahkan diri dari Kabupaten Tasikmalaya pada tahun 2001 masih menyisakan permasalahan yang belum selesai. Sengketa aset daerah yang memerlukan waktu hingga 18 tahun dari 
Tahun 2001-2019. Undang-Undang Nomor 10/2001 tentang Pembentukan Kota Tasikmalaya menyatakan bahwa Pemerintah Kabupaten Tasikmalaya harus menyerahkan seluruh asetnya yang ada di Kota Tasikmalaya.

Akan tetapi undang-undang tersebut menjadi pro dan kontra antara Pemerintah Kabupaten Tasikmalaya dan Pemerintah Kota Tasikmalaya. Pemerintah Kabupaten Tasikmalaya menolak dikarenakan sebagian aset yang ada di pemerintah Kabupaten Tasikmalaya masih dibutuhkan untuk menyumbang Pendapatan Asli Daerah (PAD) yang pada waktu itu pemerintah Kabupaten Tasikmalaya masih membutuhkan pemasukan daerah untuk menyelesaikan pembangunan infrastruktur pemerintahan baru di Singaparna yang merupakan ibu kota baru Kabupaten Tasikmalaya (Sindonews, 2013).

\section{Privotal Factor or Root Causes}

Menurut Mahmudi (dalam Rizky, 2014) aset daerah merupakan kekayaan daerah yang dimiliki serta dikuasai pemerintah daerah tersebut, yang dibeli atau diperoleh atas beban APBD maupun berasal dari hasil lainnya yang sah. Aset daerah bisa dikelompokan secara umum menjadi dua bentuk, yaitu aset keuangan dan aset non keuangan. Kas dan setara kas merupakan bagian dari aset keuangan. Sedangkan aset tetap, aset lainnya dan persediaan merupakan aset non keuangan, kemudian aset daerah dilihat dari penggunaanya dikategorikan menjadi tiga, yaitu: pertama, aset daerah yang dipakai untuk operasional pemerintah daerah.

Berdasarkan dari penggunaanya, aset daerah dikategorikan menjadi tiga, yaitu pertama, aset daerah yang dipakai buat operasional pemerintah daerah. Kedua, aset daerah yang dipakai masyarakat dalam kegiatan pelayanan publik publik. Ketiga, aset daerah yang tidak dipakai untuk pemerintah ataupun publik. Pada dasarnya aset jenis ketiga merupakan aset yang dalam pemanfaatanya belum optimal. Demi kelancaran kegiatan pemerintah pada dasarnya aset daerah menjadi hak bagi daerah pemekaran. Sengketa aset yang diperebutkan oleh Kabupaten/Kota Tasikmalaya dilatarbelakangi dengan banyaknya asset Pemerintah Kabupaten Tasikmalaya ada di wilayah Kota Tasikmalaya. Pada waktu itu, Pemerintah Kabupaten Tasikmalaya menolak menyerahkan 85 asetnya pada Pemerintah Kota Tasikmalaya, hingga Kementerian Dalam Negeri meminta pemerintah Jawa Barat turut menengahi persoalan aset itu sejak tahun 2008 hingga tahun 2013 (Yuliawati, 2013).

Aset di Stadion Olahraga Dadaha sepakat dibagi menjadi dua, kemudian kantor Sekretariat Daerah lama, dan bekas terminal Cilembang dipertahankan tetap menjadi milik Kabupaten Tasikmalaya (Sindonews, 2013). Semua aset yang ada di Kabupaten Tasikmalaya yang menjadi sengketa, sebagian besar dihibahkan ke Pemerintah Kota Tasikmalaya, seperti semua pasar di Tasikmalaya yakni Pasar Cikurubuk, Pasar Pancasila, serta Pasar Padayungan termasuk Rumah Sakit Umum Daerah (RSUD) Tasikmalaya.

Hal ini menunjukan bahwa Pemerintah Kabupaten Tasikmalaya memperoleh lebih sedikit aset yang dipergunakan untuk membangun wilayah dibandingkan Pemerintah Kota Tasikmalaya. Pembangunan di Kabupaten Tasikmalaya dimulai 
pada Tahun 2011 setelah sengketa aset. Pembangunan tersebut tertuang dalam RPJMD (Rencana Pembangunan Jangka Menengah Daerah) Tasikmalaya Tahun 20112015. Pembangunan di Kabupaten Tasikmalaya dimulai pada Tahun 2011 setelah sengketa aset. Pembangunan tersebut tertuang dalam RPJMD (Rencana Pembangunan Jangka Menengah Daerah) Tasikmalaya Tahun 2011-2015.

Tabel 1. Jumlah Aset Keseluruhan di Tasikmalaya Sebelum Pemekaran

\begin{tabular}{|c|c|c|c|}
\hline \multirow[t]{2}{*}{ No } & \multirow{2}{*}{$\begin{array}{c}\text { ASET YANG } \\
\text { DISENGKETAKAN } \\
\text { TANAH DAN } \\
\text { BANGUNAN }\end{array}$} & \multicolumn{2}{|c|}{ PASCA PEMEKARAN } \\
\hline & & KABUPATEN & KOTA \\
\hline 1 & DPRD & Terminal Indihiang & DPRD \\
\hline 2 & $\begin{array}{l}\text { Taman Alun-Alun dan } \\
\text { Monumen }\end{array}$ & $\begin{array}{c}\text { Eks terminal bus Cilembang, } \\
\text { Kantor KPPSA, Kantor UPTD } \\
\text { Dishub Kota, dan Kios }\end{array}$ & $\begin{array}{l}\text { Taman Alun-Alun dan } \\
\text { Monumen }\end{array}$ \\
\hline 3 & $\begin{array}{c}\text { Galih Pawestri dan TK } \\
\text { Pertiwi }\end{array}$ & $\begin{array}{c}\text { Kantor UPTD Balai Latihan Kerja } \\
\text { (BLK) }\end{array}$ & Galih Pawestri dan TK Pertiwi \\
\hline 4 & $\begin{array}{l}\text { Gedung KORPRI dan } \\
\text { Perpustakaan }\end{array}$ & $\begin{array}{l}\text { Ex Gudang Parmasi dan ex } \\
\text { Kandepkes }\end{array}$ & $\begin{array}{l}\text { Gedung KORPRI dan } \\
\text { Perpustakaan }\end{array}$ \\
\hline 5 & Kantor Kwarcab Pramuka & Ex Pasar dan RPH Indihiang & Kantor Kwarcab Pramuka \\
\hline 6 & $\begin{array}{c}\text { Gedung Ex Dispenda, } \\
\text { Gedung Sekretariat } \\
\text { BKPD/BPR, Kantor P2M } \\
\text { Dan Ex.PUKotip }\end{array}$ & $\begin{array}{c}\text { Komplek Gedung Negara dan } \\
\text { Pendopo }\end{array}$ & $\begin{array}{c}\text { Gedung Ex Dispenda, Gedung } \\
\text { Sekretariat BKPD/BPR, } \\
\text { Kantor P2M Dan Ex.PUKotip }\end{array}$ \\
\hline 7 & Pasar Pancasila & Bappeda & Pasar Pancasila \\
\hline 8 & Ruko/Kios pancasila Timur & Komplek Sekretariat Daerah & Ruko/Kios pancasila Timur \\
\hline 9 & $\begin{array}{l}\text { Pasar Cikurubuk dan Kantor } \\
\text { UPTD Pengelola Pasar }\end{array}$ & Gedung Satkorlak (Pabrik Es) & $\begin{array}{l}\text { Pasar Cikurubuk dan Kantor } \\
\text { UPTD Pengelola Pasar }\end{array}$ \\
\hline 10 & Pasar Besi Sumber Makmur & Gedung SPHB/BINMAS & Pasar Besi Sumber Makmur \\
\hline 11 & UPTD Pengelola Pasar & MES SKP dan Tanah Kolam & UPTD Pengelola Pasar \\
\hline 12 & Pasar Padayungan & MES Sukarendeng & Pasar Padayungan \\
\hline 13 & Pos Retribusi & Sawah, Kolam BBI Cibeuti & Pos Retribusi \\
\hline 14 & Su Terminal Cicariang & $\begin{array}{l}\text { Kantor Dinas Kehutanan dan } \\
\text { Perkebunan }\end{array}$ & Sub Terminal Cicariang \\
\hline 15 & Sub Terminal Tamansari & Ex Gedung Kantor & Sub Terminal Tamansari \\
\hline 16 & $\begin{array}{l}\text { Ex Pasar Hewan Karang } \\
\text { Sambung }\end{array}$ & Ex Dishutbun, Rumah Dinas & $\begin{array}{l}\text { Ex Pasar Hewan Karang } \\
\text { Sambung }\end{array}$ \\
\hline 17 & Kantor Dinas Pertanian & $\begin{array}{c}\text { Kantor, Gudang, dan Rumah } \\
\text { Dinas UPP }\end{array}$ & Kantor Dinas Pertanian \\
\hline
\end{tabular}


JAKPP (Jurnal Analisis Kebijakan dan Pelayanan Publik)

6(1), 15-34: Resolusi Konflik Kepemilikan Aset Publik...

\begin{tabular}{|c|c|c|c|}
\hline 18 & Kantor PUSKUD & $\begin{array}{c}\text { Eks Kantor Dishutbun dan Rumah } \\
\text { Dinas }\end{array}$ & Kantor PUSKUD \\
\hline 19 & Ex Work Shop PU Kotip & SPMA & Ex Work Shop PU Kotip \\
\hline 20 & $\begin{array}{c}\text { Kantor UPTD Bina Karya } \\
\text { Loka (BKL) }\end{array}$ & Sawah & $\begin{array}{c}\text { Kantor UPTD Bina Karya Loka } \\
\text { (BKL) }\end{array}$ \\
\hline 21 & $\begin{array}{c}\text { Kantor Sanggar Kegiatan } \\
\text { Belajar (SKB) }\end{array}$ & $\begin{array}{l}\text { Kantor UPTD Benih Padi dan } \\
\text { Palawija }\end{array}$ & $\begin{array}{c}\text { Kantor Sanggar Kegiatan } \\
\text { Belajar (SKB) }\end{array}$ \\
\hline 22 & $\begin{array}{c}\text { Kantor UPTD dan Rumah } \\
\text { Dinas SKB }\end{array}$ & Eks Rumah Dinas & $\begin{array}{c}\text { Kantor UPTD dan Rumah } \\
\text { Dinas SKB }\end{array}$ \\
\hline 23 & $\begin{array}{l}\text { Dinas Pertambangan dan } \\
\text { Energi (Komplek) }\end{array}$ & Kebun & $\begin{array}{l}\text { Dinas Pertambangan dan } \\
\text { Energi (Komplek) }\end{array}$ \\
\hline 24 & Komplek Dadaha & Eks Rumah Dinas & Komplek Dadaha \\
\hline 25 & Tanah Darat dan Sawah & Gedung Aspal & Tanah Darat dan Sawah \\
\hline 26 & UPTD DAMKAR & $\begin{array}{c}\text { Gedung Kantor Dinas Tenaga } \\
\text { Kerja dan Transmigrasi }\end{array}$ & UPTD DAMKAR \\
\hline 27 & $\begin{array}{c}\text { Tempat Penampungan Akhir } \\
\text { Batuseuneu }\end{array}$ & Gudang Kantor Disnaker KB & $\begin{array}{c}\text { Tempat Penampungan Akhir } \\
\text { Batuseuneu }\end{array}$ \\
\hline 28 & Monumen Kh.Z Mustofa & $\begin{array}{c}\text { Kantor Departemen Transmigrasi } \\
\text { dan Tanah Sawah Balai Benih } \\
\text { Palawija }\end{array}$ & Monumen Kh. Z Mustofa \\
\hline 29 & Rumah Sakit & $\begin{array}{c}\text { Dinas Peternakan dan Kelautan, } \\
\text { Laboratorium dan Bangunan } \\
\text { Kantor RPH }\end{array}$ & Rumah Sakit \\
\hline 30 & Komplek Inspektorat & Rumah Dinas & Kantor Inspektorat \\
\hline 31 & $\begin{array}{c}\text { Gedung Kantor Pariwisata } \\
\text { dan Kebudayaan }\end{array}$ & Gudang Peralatan Bencana Alam & $\begin{array}{l}\text { Gedung Kantor Pariwisata } \\
\text { dan Kebudayaan }\end{array}$ \\
\hline 32 & Wisata Taman Karang Resik & Kantor Dinas Pendidikan & Wisata Taman Karang Resik \\
\hline 33 & $\begin{array}{l}\text { Perluasan Situ } \\
\text { Gede/Rekreasi }\end{array}$ & Gunung Dalem & Perluasan Situ Gede/Rekreasi \\
\hline 34 & Rumah Dinas (Gn Koneng) & Bakso Sari Rasa No 35 H.Abbas & Rumah Dinas (Gn Koneng) \\
\hline 35 & Bloj Karoeng & “Ex Kereta Jenazah" & Bloj Karoeng \\
\hline 36 & Gedung Juang DHC 45 & Gedung Dinas Kesehatan & Gedung Juang DHC 45 \\
\hline 37 & Kantor ORGANDA & Gedung Lab Dinas Kesehatan & Kantor ORGANDA \\
\hline 38 & $\begin{array}{l}\text { Kantor Cienteung, Pasar } \\
\text { Cienteung dan Perluasan }\end{array}$ & $\begin{array}{c}\text { Kantor Badan Kepegawaian } \\
\text { Pendidikan dan Latihan (BKPLD) }\end{array}$ & $\begin{array}{l}\text { Kantor Cienteung, Pasar } \\
\text { Cienteung dan Perluasan }\end{array}$ \\
\hline 39 & Sawah dan Kolam & Rumah Dinas BKPLD & Sawah dan Kolam \\
\hline 40 & Ex Dishutbun, Rumah Dinas & Kantor BPN/SPBU & Ex Dishutbun, Rumah Dinas \\
\hline
\end{tabular}


Volume 6 No. 1, Juni 2020

pISSN: 2460-6162. eISSN: 2527-6476

\begin{tabular}{|c|c|c|c|}
\hline 41 & Sawah & Pertokoan Gunung Pereng & Sawah \\
\hline 42 & Ex Depo Sampah dan Kios & - & Ex Depo Sampah dan Kios \\
\hline 43 & Sekolah Pengatur Rawat Gigi & - & Sekolah Pengatur Rawat Gigi \\
\hline 44 & Sub Terminal Cibanjar & - & Sub Terminal Cibanjar \\
\hline 45 & Terminal Indihiang & - & - \\
\hline 46 & $\begin{array}{c}\text { Eks Terminal Bus } \\
\text { Cilembang, Kantor KPPSA, } \\
\text { Kantor UPTD Dishub Kota, } \\
\text { dan Kios }\end{array}$ & - & - \\
\hline 47 & $\begin{array}{l}\text { Kantor UPTD Balai Latihan } \\
\text { Kerja }\end{array}$ & - & - \\
\hline 48 & $\begin{array}{l}\text { Ex Gudang Farmasi dan Ex } \\
\text { Kandepkes }\end{array}$ & - & - \\
\hline 49 & Ex Pasar dan RPH Indihiang & - & - \\
\hline 50 & $\begin{array}{c}\text { Komplek Gedung Negara } \\
\text { dan Pendopo }\end{array}$ & - & - \\
\hline 51 & Bappeda & - & - \\
\hline 52 & Komplek Sekretariat Daerah & - & - \\
\hline 53 & Geung Satkorlak (Pabrik Es) & - & - \\
\hline 54 & Gedung SPHB/BINMAS & - & - \\
\hline 55 & MES SKP dan Tanag Kolam & - & - \\
\hline 56 & MES Sukarendeng & - & - \\
\hline 57 & Sawah, Kolan BBI Cibeuti & - & - \\
\hline 58 & $\begin{array}{l}\text { Kantor Dinas Kehutanan dan } \\
\text { Perkebunan }\end{array}$ & - & - \\
\hline 59 & Ex Gedung Kantor & - & - \\
\hline 60 & Ex Dishutbun, Rumah Dinas & - & - \\
\hline 61 & $\begin{array}{c}\text { Kantor, Gudang dan Rumah } \\
\text { Dinas UPP }\end{array}$ & - & - \\
\hline 62 & $\begin{array}{l}\text { Eks. Kantor Dishutbun, } \\
\text { Rumah Dinas }\end{array}$ & - & - \\
\hline 63 & SPMA & - & - \\
\hline 64 & Sawah & - & - \\
\hline 65 & $\begin{array}{c}\text { Kantor UPTD Benih Padi } \\
\text { dan Palawija }\end{array}$ & - & - \\
\hline
\end{tabular}




\begin{tabular}{|c|c|c|c|}
\hline 66 & Eks Rumah Dinas & - & - \\
\hline 67 & Kebun & - & - \\
\hline 68 & Eks Rumah Dinas & - & - \\
\hline 69 & Gedung Aspal & - & - \\
\hline 70 & $\begin{array}{c}\text { Gedung Kantor Dinas } \\
\text { Tenaga Kerja dan } \\
\text { Transmigrasi }\end{array}$ & - & - \\
\hline 71 & Gedung Kantor Disnaker KB & - & - \\
\hline 72 & $\begin{array}{c}\text { Kantor Departemen } \\
\text { Transmigrasi dan Tanah } \\
\text { Sawah Balai Benih Palawija }\end{array}$ & - & - \\
\hline 73 & $\begin{array}{l}\text { Dinas Peternakan dan } \\
\text { Kelautan, Laboratorium dan } \\
\text { Bangunan Kantor RPH }\end{array}$ & - & - \\
\hline 74 & Rumah Dinas & - & - \\
\hline 75 & $\begin{array}{c}\text { Gedung Peralatan Bencana } \\
\text { Alam }\end{array}$ & - & - \\
\hline 76 & Kantor Dinas Pendidikan & - & - \\
\hline 77 & Gunung Dalem & - & - \\
\hline 78 & $\begin{array}{c}\text { Bakso Sari Rasa No.35 } \\
\text { H.Abbas }\end{array}$ & - & - \\
\hline 79 & "Ex Kereta Jenazah" & - & - \\
\hline 80 & Gedung Dinas Kesehatan & - & - \\
\hline 81 & $\begin{array}{l}\text { Gedung Lab. Dinas } \\
\text { Kesehatan }\end{array}$ & - & - \\
\hline 82 & $\begin{array}{l}\text { Kantor Badan Kepegawaian } \\
\text { Pendidikan dan Latihan }\end{array}$ & - & - \\
\hline 83 & Rumah Dinas BKPLD & - & - \\
\hline 84 & Kantor BPN/SPBU & - & - \\
\hline 85 & Pertokoan Gunung Pereng & - & - \\
\hline
\end{tabular}

Sumber: Keputusan Bupati Tasikmalaya Nomor 030/Kep.366-DPPKAD/2013

\section{Mobilizing Factors}

Salah satu faktor penyebab konflik yang dapat di mobilisasi oleh kelompok dalam hal ini adalah kesepakatan penyerahan sejumlah aset. Pada akhirnya kesepakatan sejumlah aset yang menjadi milik Pemerintah Kabupaten maupun Pemerintah Kota diantaranya yaitu pendopo Tasikmalaya yang berada di Kota Tasikmalaya dipertahankan oleh Kabupaten Tasikmalaya karena dengan alasan 
bangunan itu menjadi ciri khas dari Kabupaten Tasikmalaya. Aset di Stadion Olahraga Dadaha sepakat dibagi menjadi dua, kemudian kantor Sekretariat Daerah lama, dan bekas terminal Cilembang dipertahankan tetap menjadi milik Kabupaten Tasikmalaya (Sofa, 2016).

Bupati Tasikmalaya lebih kearah diplomatis dalam melakukan penyelesaian konflik aset ini, ketika aset yang memang mempunyai nilai sejarah untuk Kabupaten Tasikmalaya, tentu dengan tegas menginginkan tetap aset itu milik Kabupaten Tasikmalaya (Wargani, 2018). Sementara Walikota Tasikmalaya lebih kearah gaya birokrasi bagaimana dalam menyelesaikan konflik aset ini jalan yang ditempuh adalah dengan memegang aturan-aturan yang sudah ada, namun kedua kepala daerah ini memiliki kekuatan emosional politik yang sama dengan Bupati Tasikmalaya yang berasal dari platform partai yang sama (Wargani, 2018).

\section{Aggravating factors}

Menurut Eko Prasojo dkk (dalam Rizky, 2014), menyebutkan tidak hanya pemecahan sumber daya yang dimiliki daerah dalam pemekaran daerah bahkan akan diikuti oleh pembagian. Konflik turunan yang terjadi akan sulit dihindari karena pembagian maupun pemecahan tersebut berlangsung baik ditingkat elite maupun masyarakat. Adanya kesenjangan yang muncul antar daerah dan pusat dan antar-daerah sendiri dalam kepemilikian sumber daya alam, infrastruktur ekonomi, tingkat sumber daya manusia, dan sumber daya budaya menjadi salah satu permasalah yang muncul (Wargani, 2018). Konflik muncul akibat didalamnya terdapat persaingan atau perselisihan untuk mendapatkan atau mempertahankan sesuatu yang sudah diputuskan sebelumnya.

\section{b. Resolusi Konflik Kepemilikan Asset Publik}

Pemerintah Kabupaten Tasikmalaya beserta Kota Tasikmalaya yang difasilitasi oleh Pemerintah Provinsi duduk bersama untuk menyelesaikan permasalahan ini secara bersama-sama, dengan pendekatan negosiasi akhirnya tercapai kesepakatan bersama antara Pemerintah Provinsi Jawa Barat yang diwakili oleh Gubernur, Pemerintah Kabupaten Tasikmalaya diwakili oleh Bupati, dan Pemerintah Kota Tasikmalaya diwakili oleh Walikota sehingga pada tahun 2013 sempat mendinginkan suasana dan permasalahan aset ini sempat selesai, pertemuan ini menghasilkan kesepakatan bersama dalam bentuk MOU tentang Penyelesaian Aset Pemerintah Kabupaten Tasikmalaya yang Terletak di Wilayah Kota Tasikmalaya.

Didalam MOU tersebut berisi beberapa isi kesepakatan dari kedua belah pihak yang pertama dalam menyelesaikan sengketa asset, kedua belah pihak memilih win win solution yang bertujuan sama-sama menguntungkan kedua belah pihak. Kedua, kedua pemerintah daerah tersebut diharapkan dapat lebih optimal dalam menyelenggarakan tata kelola pemerintahan di daerah masingmasing. Meskipun telah terjadi kesepakatan antara kedua belah pihak, namun sebenernya sengketa aset kedua pemerintah daerah ini belum selesai. Hal tersebut karena asset yang dianggap hak dari Pemkab Tasikmalaya saat ini terdapat di domain Pemkot. Beberapa asset tersebut yang dimaksud adalah BPBD, kolam 
renang Sukapura, Terminal Cilembang, Alun-alun, Pendopo dan Kantor Bupati, Bekas Dinas Kesehatan, Dinas Kesehatan dan Perkebunan serta beberapa sertifikat yang masih ditahan oleh Pemerintah Kabupaten Tasikmalaya. Beberapa asset tersebut yang seharusnya menjadi milik Pemerintah Kota Tasikmalaya (Fauzan, 2014).

Pada tahun 2013 pemerintah provinsi berinisiatif untuk membuat resolusi konflik dengan cara mengkolaborasikan pemerintah Kabupaten Tasikmalaya dan Kota Tasikmalaya untuk dapat menyelesaikan permasalahan aset ini dengan winwin solution Menurut Fisher et, al (2017), resolusi konflik adalah cara menyelesaikan permasalahan sebab akibat serta menciptakan dan memperbaiki kesalah pahaman yang terjadi antara pihak-pihak yang bermasalah. Sedangkan Mindes (dalam Sona, 2016) berpendapat resolusi konflik adalah aspek utama dalam pembangunan moral dan sosial yang membutuhkan cara dan keterampilan tersendiri untuk menyelesaikan permasalahan antara kedua belah pihak yang bermasalah, cara-cara menyelesaikan masalah tersebut seperti bernegosiasi, kompromi dan menerapkan sikap adil.

Resolusi konflik adalah cara menyelesaikan masalah antara kedua belah pihak yang bermasalah baik melalui proses negosiasi dan kompromi, sehingga mendapatkan titik terang dalam menyelesaikan masalah. Selain itu resolusi konflik menawarkan cara-cara penyelesaian masalah yang dianggap demokratis. Pada tahun 2019, upaya mediasi yang pertama dilakukan tanggal 16 september, dalam hal ini Kejaksaan Negeri sebagai pihak mediator. Pada mediasi pertama yang mempertemukan kedua pihak yang berkonflik tersebut pihak Pemkab Tasikmalaya dalam hal ini Bupati Tasikmalaya tidak dapat hadir dalam acara mediasi tersebut. Ketidakhadiran pihak dari Pemkab Tasikmalaya tersebut membuat mediasi pertama belum menemukan titik terang sehingga Kejaksaan Negeri mengagendakan mediasi kedua pada tanggal 23 september 2019 (https://www.radartasikmalaya.com). Berikut ini beberapa model resolusi konflik yang diterapkan dalam proses penyelesaian sengketa asset oleh Pemerintah Kabupaten dan Kota Tasikmalaya:

\section{Model Resolusi Konflik dengan Modus Kompromi/Negosiasi}

Menurut Soekanto, et.al (dalam Meriwijaya, 2017) cara menyelesaikan konflik dengan mengambil jalan tengah berdasarkan kesepakatan kedua belah pihak yang berkonflik dan mempunyai hubungan kerjasama yang sedang. Modus kompromi/ negosiasi ini dilakukan dengan strategi take and give, sehingga terdapat cara pemecahan masalah yang memuaskan kedua belah pihak.

Pada waktu yang bersamaan masing-masing memberikan dan menawarkan sesuatu dan saling memberi atau menerima serta meminimalisir kekurangan semua pihak yang bisa menguntungkan semua pihak. Pemerintah Kabupaten Tasikmalaya beserta Kota Tasikmalaya yang difasilitasi oleh Pemerintah Provinsi duduk bersama untuk menyelesaikan permasalahan ini secara bersama-sama, dengan pendekatan negosiasi akhirnya tercapai kesepakatan bersama antara Pemerintah Provinsi Jawa Barat yang diwakili oleh 
Gubernur, Pemerintah Kabupaten Tasikmalaya yang diwakili oleh Bupati, dan Pemerintah Kota Tasikmalaya yang diwakili oleh Walikota sehingga pada tahun 2013 tercapainya kesepakatan bersama dalam penyelesaikan konflik perebutan aset, dengan prinsip saling menguntungkan kedua belah pihak.

Pertemuan ini menghasilkan kesepakatan bersama yaitu tentang Penyelesaian Aset Pemerintah Kabupaten Tasikmalaya yang Terletak di Wilayah Kota Tasikmalaya Nomor: 130/24Otdaksm, Nomor: 073/Ksd.13-Pe/X/2013 dan Nomor: 028/MoU.38-Aset/2013 (Fauzan, 2014). Dari pertemuan tersebut terdapat dua cara penyelesain konflik yaitu, pertama dari total 85 aset di kota yang dipermasalahkan antara lain pendopo Tasikmalaya, Lapangan Dadaha, bekas gedung Setda Kabupaten Tasikmalaya, sejumlah pasar dan gedung dinas. Sebanyak 40 aset diantaranya Pendopo, eks Terminal Cilembang dan sebagian kompleks sarana olahraga Dadaha akan diserahkan kembali kepada Kabupaten.

Selanjutnya, hasil dari pertemuan antara Bupati dan Walikota yang difasilitasi oleh Gubernur Jawa Barat menghasilkan keputusan pembagian aset atau penghibahan kembali oleh pihak Kota Tasikmalaya. Dari kesepakatan yang sudah dibuat, proporsi untuk kota lebih besar yaitu dari 85 aset 45 aset diserahkan kepada Kota Tasikmalaya, yaitu berbagai aset yang sudah dikelola dan diperbaiki oleh kota seperti seluruh Pasar yang ada di Tasikmalaya, begitupun dengan Rumah Sakit Umum Daerah Tasikmalaya diserahkan kepada pihak kota.

\section{Model Resolusi Konflik dengan Modus Mediasi}

Menurut Soerjono Soekanto (dalam Meriwijaya, 2017), model resolusi konflik dengan modus medisi adalah proses menyelesaikan masalah dengan cara melibatkan pihak ketiga sebagai mediator atau fasilitator. Pemilihan modus ini dipilih atau diterapkan karena kedua belah pihak tidak dapat menyelesaikan masalahnya sendiri sehingga membutuhkan pihak ketiga sebagai mediator yang dapat menjadi penengah untuk kedua belah pihak. Mediasi ini dilakukan di tempat dan waktu yang sama serta menghadirkan kedua belah pihak yang terkait, sehingga dalam mediasi ini membutuhkan waktu dan take and give.

Pada saat proses mediasi pertama di tahun 2013 lalu, Gubernur Jawa Barat menjadi mediator karena pada saat itu Kabupaten Tasikmalaya belum memiliki stadion di wilayahnya. Beberapa waktu lalu permasalahan perebutan aset kawasan sarana olahraga Dadaha memanas kembali karena pihak Pemkab Tasikmalaya belum menyerahkan sertifikat aset tersebut ke pihak Pemkot Tasikmalaya, padahal berdasarkan kesepakatan kedua belah pihak ini pada tahun 2012 apabila dilihat secara de Jure dan de Facto stadion olahraga tersebut sudah resmi menjadi aset Pemkot Tasikmalaya.

Pada tahun 2019, upaya mediasi yang pertama dilakukan tanggal 16 september lalu, dalam hal ini Kejaksaan Negeri sebagai pihak mediator. Pada mediasi pertama yang mempertemukan kedua pihak yang berkonflik tersebut pihak Pemkab Tasikmalaya dalam hal ini Bupati Tasikmalaya tidak dapat hadir dalam acara mediasi tersebut. Ketidakhadiran pihak dari Pemkab Tasikmalaya tersebut membuat mediasi pertama belum menemukan titik terang sehingga 
Kejaksaan Negeri mengagendakan mediasi kedua pada tanggal 23 september 2019 (https://www.radartasikmalaya.com).

Dari pihak Pemkab Tasikmalaya yang waktu itu diwakili pejabat sementara Sekda Kabupaten Tasikmalaya ketika ditanyakan kesanggupannya untuk menyerahkan sertifikat aset olahraga Dadaha, Pejabat sementara Sekda Kab Tasikmalaya menjawab bahwasannya akan melaporkan terlebih dahulu ke pimpinannya. Ketika ditanya terkait dengan ketidakhadiran Bupati Tasikmalaya, pejabat sementara Sekda Tasikmalaya menjawab bahwasannya ketidakhadiran Bupati tersebut dalam penyerahan sertifikat aset daerah sangat disayangkan, sebab perwakilnnya pun tidak punya kuasa untuk menentukan penyerahan sertifikat tersebut kepada pihak Pemkot Tasikmalaya.

Mediasi penyelesaian masalah hukum bidang perdata antara Pemerintah Kota Tasikmlaaya dengan Pemerintah Kabupaten Tasikmalaya yang dilaksanakan di Hotel Grand Metro, pada tanggal 16 september 2019. Dalam acara ini dihadiri Wali Kota Tasikmalaya, Pelaksana harian (Plh) Sekretaris Daerah Kabupaten Tasikmalaya beserta jajarannya, Plh Kejari Kota Tasikmalaya. Turut mendampingi Plh Sekretaris Daerah Kota Tasikmalaya, Staf Ahli Bidang Pemerintahan, Hukum Dan Politik, Kepala Bagian Pemerintahan, Kepala Bagian Hukum. Saat ditemui awak media, Wali Kota Tasikmalaya Drs. H. Budi Budiman mengatakan pihak Pemkot Tasikmalaya sudah mengirim surat kepada Ibu Kejari Kota Tasikmalaya untuk melakukan mediasi terkait dengan aset-aset yang sudah diserahkan ke Kota Tasikmalaya namun ada beberapa sertifikat yang belum diserahkan, termasuk sertifikat aset Dadaha yang 15 hektar (www.radartasikmalaya.com).

Akhirnya pada tahun 2019 Pemerintah Kabupaten Tasikmalaya menyerahkan sejumlah sertifikat aset Komplek Dadaha ke Pemerintah Kota Tasikmalaya. Sejumlah sertifikat aset tersebut akhirnya bisa diserahkan langsung Bupati Tasikmalaya dan diterima langsung oleh Wali Kota Tasikmalaya. Pihak Pemkot Tasikmalaya sangat bersyukur dan merasa lega karena permasalahan sengketa aset yang sudah berlangsung selama 18 tahun tersebut dapat terselesaikan.

Penyerahan sertifikat aset terlaksana berkat adanya upaya mediasi yang di inisiasi oleh Kejaksaan Negeri di dua pemerintah daerah. Beberapa tahun penyerahan sertifikataset tersebut memang kerap menemui kendala. Dalam penyerahan sertifikat aset sarana olahraga tersebut, Pemkab Tasikmalaya bukan tanpa syarat. Pemkab Tasikmalaya meminta agar Pemkot Tasikmaya ikut mendorong ke Pemerintah Provinsi Jawa Barat agar menyelesaikan proyek Sarana Olahraga (SOR) di wilayahnya yang saat ini terbengkalai. Seperti yang sudah dijelaskan sebelumnya di atas, pada tahun 2013 pihak Pemerintah Provinsi Jawa Barat memfasilitasi mediasi antara kedua daerah yang bersengketa ini. Dari pihak Pemerintah Kota Tasikmalaya mengatakan bahwa, kami tahu persis bapak Ade (Bupati Tasikmalaya) mengetahui lebih dalam terkait "aset ini ketika beliau masih duduk di DPRD Kabupaten Tasikmalaya". 


\section{Kesimpulan}

Berdasarkan hasil analisis dari penulis dapat disimpulkan sebagai berikut: sebagai berikut: faktor-faktor penyebab terjadinya konflik perebutan sengketa aset daerah antara Pemerintah Kabupaten Tasikmalaya dengan Kota Tasikmalaya yaitu adanya kepentingan dari masing-masing pihak terutama dengan latar belakang politik yang berbeda membuat konflik ini semakin panas, namun pada tahun 2013 sedikit mendinginkan situasi yang selama hampir 12 tahun memanas yaitu dengan keluarnya Keputusan Pemerintah Provinsi Jawa Barat.

Resolusi konflik yang digunakan dalam menyelesaikan permasalahan sengketa perebutan aset menggunakan dua model resolusi konflik yaitu negosiasi dan mediasi. Resolusi konflik yang pertama yaitu, ketika kedua pemerintah daerah ini difasilitasi oleh Pemerintah Provinsi menyelesaikan permasalahan secara bersama-sama dengan pendekatan negosiasi, kemudian permasalahan asset ini sempat selesai pada tahun 2013 dengan adanya MOU kesepakatan kedua belah pihak.

Model resolusi konflik yang kedua yaitu mediasi. Pada tahun 2019 Pemerintah Kabupaten Tasikmalaya menyerahkan sejumlah sertifikat aset Komplek Dadaha ke Pemerintah Kota Tasikmalaya. Sejumlah sertifikat aset tersebut akhirnya bisa diserahkan langsung Bupati Tasikmalaya dan diterima langsung oleh Wali Kota Tasikmalaya. Penyerahan sertifikat aset terlaksana berkat adanya upaya mediasi yang di inisiasi oleh Kejaksaan Negeri di dua pemerintah daerah. Beberapa tahun penyerahan sertifikat aset tersebut memang kerap menemui kendala. Dalam penyerahan sertifikat aset sarana olahraga itu, Pemkab Tasikmalaya bukan tanpa syarat. Pemkab Tasikmalaya meminta agar Pemkot Tasikmaya ikut mendorong ke Pemprov Jabar agar menyelesaikan proyek SOR di wilayahnya yang saat ini terbengkalai.

\section{Daftar Pustaka}

Akbar, S. (2019). Analisa Masalah-Masalah Yang Muncul Dalam Pemekaran Wilayah Baru Pada Penyelengaraan Otonomi Daerah. JIAGANIS, 3(1).

Aprizal, H. (2017). Evaluasi Pelaksanaan Pengelolaan Barang Milik Daerah/Aset Pemerintah Kabupaten Sambas. Jpmis.

Dewi, A. S. (2015). Evaluasi Dampak Kebijakan Pemekaran Wilayah Di Kabupaten Batu Bara. Medan: Universitas Sumatera Utara.

Dewi, I. K.(2017).Mediasi Konflik Pertambanga Galian C Di Desa Karanggedang Kecamatan Bukateja Kabupaten Purbalingga Tahun 2013-2016.

Dhedhu, K. M., Erviantono, T., \& Yudharta, I. P. D. (2017). Pengelolaan Aset Daerah Hasil Pemisahan Aset dari Kabupaten Induk (Studi Kasus pada Dinas Pendapatan, Pengelolaan Keuangan dan Aset Daerah Kabupaten NagekeoNTT). Citizen Charter, 1(1). 
Ginting, H. V. (2017). Sistem Pengamanan Terhadap Aset Tidak Bergerak Pada Badan Pengelolaan Keuangan Dan Aset Daerah Provinsi Sumatera Utara. Medan: Universitas Sumatera Utara.

Fauzan, M., \& Pamuji, K. (2014). Model Kerjasama Antar Daerah dalam Penyelesaian Sengketa Kewenangan pada Daerah Kabupaten/kota Hasil Pemekaran. Media Hukum, 21(2), 16.

Halim, R. S. (2013). Faktor-Faktor Yang Mempengaruhi Pengelolaan Aset Pasca Pemekaran Wilayah Dan Pengaruhnya Terhadap Kualitas Laporan Keuangan Pemerintah Di Kabupaten Tapanuli Selatan. Jurnal Ekonomi Dan Bisnis Volume 13. Nomor 02, 31-33.

Jalil, M. (2014). Strategi Komunikasi Tokoh Masyarakat Dalam Menyelesaikan Konflik Sengketa Tanah Di Pasir Belengkong Kecamatan Pasir Belengkong Kabupaten Paser. Ejournal Ilmu Komunikasi, 2014, Volume 2 Nomor 4, 15-29.

Mahruddin, M. (2017). Implikasi Kebijakan Pemekaran Desa terhadap Redistribusi Aset dan Penetapan Administrasif Pemerintahan. Al-'Adl, 10(2), 117137.

Marjak, M (2016).Politik Pemekaran Wilayah "Studi Kasus Kegagalan Pembentukan Kabupaten Lombok Selatan Tahun 2014".

MOMO, L. A. (2016). Konflik Peraturan Kepemilikan Aset Daerah Akibat Pemekaran Daerah (Studi Kasus Peraturan Kepemilikan Aset Daerah antara Pemerintah Kabupaten Buton dengan Pemerintah Kota Baubau) (Doctoral dissertation, Universitas Gadjah Mada).

Novalia Arifin, V., Kahar, H., \& Loesida, R. Analisis Efektivitas Inventarisasi Aset Daerah Pasca Pemekaran (Studi Kasus Pasca Pemekaran Di Kota Lubuklinggau Provinsi Sumatera Selatan) (Doctoral Dissertation, Fakultas Ilmu Sosial Dan Ilmu Politik Unib).

Patimah, T. (2017). Pengaruh Penatausahaan Aset Tetap Terhadap Kewajaran Laporan Keuangan Pemerintah Daerah (Studi Kasus Pada Pemerintah Kota Tasikmalaya). Bandung: Politeknik Negeri Bandung.

Rahmawati, A. (2017). Kolaborasi Antar Daerah Dalam Penyelesaian Konflik Antar Nelayan Di Perairan Pacitan, Wonogiri Dan Gunungkidul. Paradigma: Jurnal Ilmu Administrasi, 5(2), 148-168.

Ramadhani, M. H. (2014). Permasalahan hukum dari pemekaran daerah terhadap aset aset milik daerah induk dan daerah hasil pemekaran= Legal issue of regional expansion against assets of parent region and region of the results of expansion.

Rizky, M. (2014). Konflik aset di daerah pemekaran studi konflik serah terima aset pasar tradisional di Tangerang Selatan. 
Rusdi, (2011).Peran Gubernur Maluku Dalam Resolusi Konflik Agama Di Ambon 2003-2008.

Sadali, A. R. (2013). Dampak Pemekaran Dan Konflik Pemerintah Daerah (Studi Kasus Pemekaran Kabupaten Tasikmalaya Dan Sengketa Aset Pasca pemekaran Periode 2001-2013). Depok: Universitas Indonesia.

Sakinah, A. (2015). Studi Deskriptif Tentang Model Resolusi Konflik Dalam Rencana Pembangunan Jalan Tol Tengah Kota Surabaya. Jurnal Kebijakan dan Manajemen Publik, 177-186.

Simamora, R., \& Halim, A. (2015). Faktor-faktor yang mempengaruhi pengelolaan aset pasca pemekaran wilayah dan pengaruhnya terhadap kualitas laporan keuangan Pemerintah di Kab. Tapanuli Selatan. Jurnal Ekonomi dan Bisnis, 10(1).

Sofa, N. A. (2016). Pembangunan Daerah Pasca Pemekaran Di Kabupaten Tasikmalaya Pada Tahun 2011-2015. Yogyakarta: Universitas Muhammadiyah Yogyakarta.

Sona, I. (2016). Resolusi konflik pada masa Khulafa'ar-Rasyidin (Doctoral dissertation, UIN Walisongo).

Wargani, C. (2017). Strategi Penyelesaian Konflik Dalam Perebutan Aset Daerah Pasca-Pemekaran Daerah (Studi Kasus Kabupaten Tasikmalaya Dengan Kota Tasikmalaya Periode 2001-2018)

Internet

Diakses pada 06 Agustus 2019 dari (https:// www.radartasikmalaya.com).

$\begin{array}{llll}\text { Diakses } & \text { pada } & 18 & \text { april }\end{array}$ https:/ / daerah.sindonews.com/read/794768/21/sengketa-85-aset-ditasikmalaya-tuntas-1381908814 